FNG \& Bilim Tip Transplantasyon Dergisi 2017;2(1):21-23

doi: 10.5606/fng.transplantasyon.2017.004

\title{
Kanser immünoterapisi
}

\author{
Cancer immunotherapy
}

\author{
Ahmet Anıl Özlük, Merve Güner Oytun, Damla Günenç \\ Ege Üniversitesi Tip Fakültesi, İç Hastalıkları Anabilim Dal, İzmir, Türkiye
}

$\ddot{O Z Z}$

İmmünoterapi, hastanın kendi bağışıklık sistemine ait belli bölümlerin kanseri de içeren bir grup hastalıkla mücadele etmek üzere kullanıldığı bir tedavi biçimidir. Amaç immün sisteme ait hücrelerin kanser hücrelerini hedef alarak onları yok etmelerini sağlamaktır. Çeşitli yolakları etkileyerek bu etkilerini ortaya çıkarırlar. Monoklonal antikorlar, immün sistem kontrol inhibitörleri, kanser aşıları bu yolakları etkileyen mekanizmalardır. Bu yolaklar içerisinde en sık kullanılan ve onay alanı monoklonal antikorlardır. Bu alanda yapılan çalışmalar artmaktadır ve yeni hedef olarak antijenlerin bulunması ile kemoterapinin yerini immünoterapinin alması beklenmektedir.

Anahtar sözcükler: Kanser immünoterapisi; immünoterapi; monoklonal antikor.

\section{ABSTRACT}

Immunotherapy is a type of treatment of a group of diseases, including cancer, that is based on the specific parts of the patient's own immune system. The aim is to make the immune system cells target the cancer cells and kill them. They reveal their effect by influencing various pathway. Monoclonal antibodies, immune system control inhibitors and cancer vaccines are the mechanisms that affect these pathways. Monoclonal antibodies are the most frequently used one among these mechanisms. Studies in this field are increasing and it is expected that immunotherapy will replace chemotherapy with the finding of antigens as a new objective,

Keywords: Cancer immunotherapy; immunotherapy; monoclonal antibody.

İmmünoterapi, bir kişinin kendi bağışıklık sistemine ait belli bölümlerin kanseri de içeren bir grup hastalıkla mücadele etmek üzere kullanıldığı bir tedavi biçimidir. Amaç immün sisteme ait hücrelerin kanser hücrelerini hedef alarak onları yok etmelerini sağlamaktır. İmmünoterapi farklı şekillerde etki gösteren tedavileri içermektedir. Bazı kanser türlerinde tek başına etkili olurken, bazılarında ise diğer tedavi yöntemleri ile birlikte kullanıldığında etkinliğinin arttığı bilinmektedir.

Kanser immünoterapisindeki temel amaç, tümör hücresi tarafından çeşitli yollarla susturulmuş olan immün sistemi yeniden aktive etmek ve tümör hücrelerini tanır hale getirmektir.
Bu konuda üç temel yaklaşım söz konusudur. Bunlardan ilki tümörle ilgili antijenlerin hedef alındığı monoklonal antikor aracılı hücre ölümü, ikincisi non-antijen spesifik immün sistem modülasyonu yapan check point inhibitörleri ve üçüncüsü de tümör ilişkili antijenler aracilığıyla immün sistemin $\mathrm{T}$ helper, $\mathrm{T}$ sitotoksik hücrelerini uyarmayı ve uygun antikor oluşumunun tetiklenmesi hedefleyen terapötik kanser aşılarıdır.

\section{IMMÜNOTERAPI ÇEŞITLERI}

- Monoklonal antikorlar

- İmmün sistem kontrol inhibitörleri

- Kanser aşıları 


\section{MONOKLONAL ANTIKORLAR}

Kanser immünoterapisi yöntemlerinden klinik uygulamada en sik kullanılan ve onay alanı monoklonal antikorlardır. Bağışıklık sistemi yabancı maddelere karşı antikor üreterek vücudun savunmasını sağlar. Antikorlar antijen olarak adlandırılan spesifik proteinlere bağlanırlar. Belirli bir antijeni hedefleyen spesifik antikorlara monoklonal antikor denir. Monoklonal antikorlar aralarında kanserin de bulunduğu bazı hastalıkların tedavisinde kullanılmaktadır. Tedavide en sık kullanılan çıplak monoklonal antikorlar kendiliğinden çalışan antikorlardır, bunlara bağlanan herhangi bir ilaç ya da radyoaktif madde yoktur. Çıplak monoklonal antikorlar kanser hücreleri üzerindeki antijenlere bağlanır, ancak bazıları kanserli olmayan diğer hücrelerdeki antijenlere bağlanarak veya serbest yüzen proteinlere bağlanarak çalışmaktadır. ${ }^{[1]}$ Çıplak antikorlar farklı yollarla çalışırlar. Örneğin; kronik lenfositik lösemili (KLL) bazı hastaların tedavisinde kullanılan Alemtuzumab; lenfosit hücrelerindeki CD52 antijenlerine bağlanır. Bu bağlanan antikorlar KLL hücrelerini yok etmek için bağışıklık sistemi hücrelerini çağırarak etki ederler. .1,2] Bir diğer çıplak monoklonal antikor olan trastuzumab, mide ve meme kanseri hücresi yüzey proteinlerinden olan HER2'ye bağlanarak etki eder. ${ }^{[1,3]}$

Konjuge monoklonal antikorlar kemoterapötik ilaçlara veya radyoaktif partiküllere eklenerek etki ederler. Monoklonal antikorlar bu kemoterapötik ilaçları veya radyoaktif partikülleri kanser hücrelerine götürmek için hedef olarak çalışırlar.

Radyoaktif işaretli monoklonal antikorlar, bu monoklonal antikorlara küçük radyoaktif parçacıklar eklenerek etki ederler. Ibritumomab tiuxetan radyoaktif işaretli monoklonal antikorlara örnektir, lenfositlerde bulunan CD20 antijenine karşı olan bir antikordur. Bazı non-Hodgkin lenfoma türlerinin tedavisinde kullanılır. ${ }^{[1,4]}$

Kimyasal olarak işaretlenmiş antikorlar, güçlü kemoterapötik etkiye sahip antikorlardır. Bunlara örnek olarak brentixumab lenfositlerin üzerinde bulunan CD30 antijenini hedef alan monoklonal antikorlardır. Hodgkin hastalığı ve anaplastik büyük hücreli lenfomanın tedavisinde kullanılır. Yine bir diğer örnek olarak trastuzumab emtansine (TDM-1), HER-2 proteinini hedefleyen monoklonal antikordır. ${ }^{[1,3]}$
Bispesifik monoklonal antikorlar, iki farklı monoklonal antikordan oluşur, bu yüzden aynı anda iki farklı antijene bağlanabilirler. Blinatumomab bu monoklonal antikorlara örnek olarak verilebilir. Bu monoklonal antikorlar bazı akut lenfositik lösemi tiplerinde kullanılır. Blinatumomab'in bir parçası lösemi ve lenfoma hücreleri üzerinde bulunan CD19'a bağlanırken, diğer parçası kök hücre veya $\mathrm{T}$ lenfosit üzerinde bulunan CD3'e bağlanır. ${ }^{[1,5-7]}$

\section{IMMÜN KONTROL INHIBBITÖRLERI}

İmmün kontrol inhibitörleri, immün sistemin kanser hücrelerine karşı saldırıya geçmesini engelleyen kontrol mekanizmasını (frenlemeyi) ortadan kaldırarak immün sistemin saldırıya geçmesini sağlamaktadır. PD-1 (Programmed cell death protein 1), immün sistemin $\mathrm{T}$ hücreleri üzerinde bulunan bir kontrol proteinidir. Bir diğer deyişle $\mathrm{T}$ hücrelerin vücudun kendi hücrelerine saldırmasin1 engellemektedir.

PD-1 inhibitörlerine örnek olarak, pembrolizumab ve nivolumab verilebilir. Bu ilaçların çeşitli kanser türlerinde etkili olduğu gösterilmiştir. Bu kanser türlerine örnek olarak melanomlar, küçük hücreli dışı akciğer kanserleri, baş-boyun kanserleri ve Hodgkin hastalığı verilebilir. ${ }^{[8,9]}$ CTLA-4 (cytotoxic T-lymphocyte-associated protein 4), $\mathrm{T}$ hücrelerinde bulunan immün sistemi kontrol altında tutabilmek için "off switch" olarak da adlandırılan kapalı anahtar gibi davranan proteinlerdir ve vücudun bağışık yanıt oluşturmasını baskilar.

İpilumumab, CTLA-4'e bağlanan ve çalışmasını durduran bir monoklonal antikordur. Bu immün sistemin kanser hücrelerine karşı tepkisini artırır. Bu monoklonal antikor melanom tedavisinde kullanılmaktadır. ${ }^{[1,8,9]}$

\section{KANSER ASSILARI}

Kanser tedavisinde kullanılan aşlar virüslere karşı geliştirilen aşılardan farklıdır. Bu aşılar immün sistem hücrelerinin, kanser hücrelerine karşı bir saldırı oluşturmasını sağlayarak etki etmeye çalışırlar. Amaç, hastalığı önlemek yerine var olan hastalığa karşı immün savunma oluşturmaktır. Kanser așıları, kanser hücrelerinden, hücre parçalarından ya da sadece antijenlerden oluşmaktadır. Assılar genellikle immün sistemin etkisini artırmak için adjuvan adı verilen diğer yardımcı maddelerle birleştirilir. Sipuleucel-T FDA 
tarafından onaylı prostat kanserli hastalara uygulanan bir aşıdır. Aşı her ne kadar kür sağlamasa da sağkalımı olumlu yönde etkilemektedir. ${ }^{[1,10,11]}$

Kanseri önlemeye yardımcı aşılar da bulunmaktadir. Bu aşılar kansere neden olabilecek viral enfeksiyonları önleyerek etki gösterirler. Örneğin; human papilloma virüs servikal, anal ve bazı diğer kanserlerin etyolojisinde yer almaktadır. Human papilloma virüsüne karşı geliştirilen aşlar bu kanserlerin önlenmesinde yardımc1dır. ${ }^{[1,12]}$ Yine bir diğer örnek olan hepatit $\mathrm{B}$ virüs enfeksiyonunun karaciğer kanseri ile ilişkili olduğu bilinmektedir. Bu virüse karşı geliştirilen aşı hepatit B'ye bağlı karaciğer kanserinin önlenmesinde yardımcidır. ${ }^{[1]}$

Sonuç olarak, immünoterapi kanser çalışmalarında çok büyük ve çok hızlı gelişmekte olan bir alanı oluşmaktadır. Tümör immünolojisi alanında yapılan çalışmalar artmakta ve hedef antijenlerin belirlenmesi, yeni yolakların bulunması ile kanser tedavisinde yeni tedavi yöntemleri ortaya çıkmaktadır. Gelecekte pek çok kanser türünün tedavisinde kemoterapinin yerini immünoterapinin alması beklenmektedir.

\section{Çıkar çakışması beyanı}

Yazarlar bu yazının hazırlanması ve yayınlanması aşamasında herhangi bir çıkar çakışması olmadığını beyan etmişlerdir.

\section{Finansman}

Yazarlar bu yazının araştırma ve yazarlık sürecinde herhangi bir finansal destek almadıklarını beyan etmişlerdir.

\section{KAYNAKLAR}

1. Yang Y. Cancer immunotherapy: harnessing the immune system to battle cancer. J Clin Invest 2015;125:3335-7.

2. Varghese AM, Howard DR, Pocock C, Rawstron AC, Follows G, McCarthy H, et al. Eradication of minimal residual disease improves overall and progression- free survival in patients with chronic lymphocytic leukaemia, evidence from NCRN CLL207: a phase II trial assessing alemtuzumab consolidation. $\mathrm{Br} \mathrm{J}$ Haematol 2016 Dec 29.

3. Verma S, Miles D, Gianni L, Krop IE, Welslau M, Baselga $\mathrm{J}$, et al. Trastuzumab emtansine for HER2positive advanced breast cancer. $\mathrm{N}$ Engl $\mathrm{J}$ Med 2012;367:1783-91.

4. Mondello P, Cuzzocrea S, Navarra M, Mian M. 90 Y-ibritumomab tiuxetan: a nearly forgotten opportunityr. Oncotarget 2016;7:7597-609.

5. Fry TJ, Mackall CL. T-cell adoptive immunotherapy for acute lymphoblastic leukemia. Hematology Am Soc Hematol Educ Program 2013;2013:348-53.

6. Topp MS, Kufer P, Gökbuget N, Goebeler M, Klinger M, Neumann S, et al. Targeted therapy with the T-cellengaging antibody blinatumomab of chemotherapyrefractory minimal residual disease in B-lineage acute lymphoblastic leukemia patients results in high response rate and prolonged leukemia-free survival. $\mathrm{J}$ Clin Oncol 2011;29:2493-8.

7. Hodi FS, O'Day SJ, McDermott DF, Weber RW, Sosman JA, Haanen JB, et al. Improved survival with ipilimumab in patients with metastatic melanoma. $\mathrm{N}$ Engl J Med 2010;363:711-23.

8. Larkin J, Chiarion-Sileni V, Gonzalez R, Grob JJ, Cowey CL, Lao CD, et al. Combined Nivolumab and Ipilimumab or Monotherapy in Untreated Melanoma. N Engl J Med 2015;373:23-34.

9. Ault KA. Effect of prophylactic human papillomavirus L1 virus-like-particle vaccine on risk of cervical intraepithelial neoplasia grade 2 , grade 3, and adenocarcinoma in situ: a combined analysis of four randomised clinical trials. Lancet 2007;369:1861-8.

10. Higano CS, Schellhammer PF, Small EJ, Burch PA, Nemunaitis J, Yuh L, et al. Integrated data from 2 randomized, double-blind, placebo-controlled, phase 3 trials of active cellular immunotherapy with sipuleucel-T in advanced prostate cancer. Cancer 2009;115:3670-9.

11. Fry TJ, Mackall CL. T-cell adoptive immunotherapy for acute lymphoblastic leukemia. Hematology Am Soc Hematol Educ Program 2013;2013:348-53.

12. Schlom J. Therapeutic cancer vaccines: current status and moving forward. J Natl Cancer Inst 2012;104:599-613. 